\title{
Self-Fulfilling Debt Crises, Fiscal Policy and Investment*
}

\author{
Carlo Galli ${ }^{\dagger}$
}

February 21, 2019

\begin{abstract}
This paper studies the circular relationship between sovereign credit risk, government fiscal and debt policy, and output. I consider a sovereign default model with fiscal policy and private capital accumulation. I show that, when fiscal policy responds to borrowing conditions in the sovereign debt market, multiple equilibria exist where the expectations of lenders are self-fulfilling. In the bad equilibrium, pessimistic beliefs make sovereign debt costly. The government substitutes borrowing with taxation, which depresses private investment and future output, increases default probabilities and verifies lenders' beliefs. This result is reminiscent of the European debt crisis of 2010-12: while recessionary, fiscal austerity may be the government best response to excessive borrowing costs during a confidence crisis.
\end{abstract}

Keywords: Self-fulfilling debt crises; sovereign default; multiple equilibria; fiscal austerity. JEL Codes: E44, E62, F34

*I am deeply indebted to Marco Bassetto for his invaluable advice and guidance, and to Wei Cui for insightful discussions. For helpful comments, I am grateful to Manuel Amador, Luigi Bocola, Juan Pablo Nicolini, Morten Ravn, Neele Balke, Gadi Barlevy, Javier Bianchi, V.V. Chari, Satyajit Chatterjee, Giulio Fella, Ralph Luetticke, Albert Marcet, Davide Melcangi, Fabrizio Perri, Franck Portier, Víctor Ríos-Rull, Vincent Sterk, Pedro Teles, Mark Wright and Jing Zhang. I also thank workshop participants at University College London, University of Minnesota, Universitat Autonoma de Barcelona, Queen Mary University of London and Universidad Carlos III de Madrid.

$\dagger$ Department of Economics, University College London and Centre for Macroeconomics. Address: Drayton House, 30 Gordon Street, London WC1H 0AX. Email: carlo.galli.14@ucl.ac.uk 


\section{Introduction}

The European debt crisis of 2010-12 raised, in both academic and policy circles, two important issues: one relates to the possibility of self-fulfilling debt crises in sovereign debt markets, the other to the effectiveness of austerity policies. Pessimistic investors' beliefs on government solvency have often been cited to explain, at least partly, the spike observed in government bond spreads during late 2010, and their subsequent reduction following interventions by the European Central Bank. Austerity policies have sparked a heated debate during the crisis, when fiscal consolidation measures were adopted by southern European countries as a response to the turbulence in sovereign debt markets. Some considered these policies necessary to reduce debt levels and decrease exposure to debt market fluctuations; others argued that their effects were largely contractionary and worsened the debt crisis.

These two issues are related by the existence of a negative feedback loop between bond spreads, government fiscal and debt policy, and economic activity. Bond spreads can have a significant impact on policy, because they affect the cost of government borrowing and in turn its decisions regarding the mix between debt and fiscal policy. There is ample descriptive evidence that the turmoil in sovereign debt markets observed during the European debt crisis was a concern for policymakers, and in many occasions the motivation for austerity measures that proved to adversely impact consumption, investment and output. The dependence of government bond prices on economic activity closes the circle, as default incentives tend to be increasing in debt/GDP ratios, being stronger during recessions and when debt stocks are large.

This paper studies in detail the circular relationship between spreads, policy and output, providing a tractable framework to characterise under what conditions there may exist multiple equilibria where the beliefs of sovereign debt market participants are self-fulfilling. In the model, a confidence crisis makes it costlier for the government to obtain external funding, forcing it to increase domestic taxation instead. Higher taxes depress private investment and in turn future output, increasing future default probabilities and ultimately verifying lenders' pessimistic beliefs, resulting in an equilibrium that is bad for the government. If instead borrowing conditions are

favourable, the government can borrow more cheaply and tax less, so investment is high and 
default probabilities are in turn low. The bad equilibrium illustrates situations where fiscal consolidation is the government best response to excessive borrowing costs, even though it has contractionary effects and is accompanied by low domestic welfare.

I propose a simple two-period model building on the tradition of Eaton and Gersovitz (1981) and the subsequent quantitative work of Aguiar and Gopinath (2006) and Arellano (2008). I consider a risk-averse, benevolent government that trades defaultable debt with a continuum of foreign risk-neutral investors, and taxes domestic households. Households accumulate capital, produce according to a concave production technology, pay taxes to the government and consume. The government chooses debt, tax and default policy to maximise the utility of domestic households, who suffer a random utility cost in case of default. I assume that the government cannot commit to future actions, and that tax policy and private investment are chosen after the debt auction. This key assumption implies that the government adjusts to external borrowing conditions with debt as well as fiscal policy, and the latter affects the private sector consumption-saving decision. Private investment determines future output and, in turn, future default incentives, which affect debt prices via lenders' expectations. This circular relationship between government bond prices, fiscal policy and private investment creates the possibility of multiple equilibria driven by self-fulfilling expectations on the side of foreign investors.

Following the quantitative literature, I assume that the government moves first in the debt issuance game, choosing debt at maturity (i.e. fixing its future repayment obligations). Lenders then bid a price, being willing to lend to the government as long as they make zero profits in expectation. For some levels of debt issuance, there exist multiple debt prices that satisfy such zero-profit condition. This coordination problem among lenders is the key mechanism behind the existence of multiple equilibria in the model. It relies on the effect that debt prices have, via government taxation, on household wealth in the first period, which in turn affects investment and government default incentives. I adopt a selection criterion that rules out unstable outcomes, and determines the prices on which creditors coordinate and the terms at which the government can borrow. I then characterise with a general proposition the optimal policy of the government as a function of the debt price schedule it faces and of its initial endowment, and show with 
a numerical example the existence of multiple equilibria that depend on lenders' self-fulfilling beliefs.

I choose the current specification of the model because it is tractable and allows to present the main mechanism in a transparent way. The results of the paper however are general, in the sense that the feedback loop linking bond spreads, output and default incentives can also be modelled in other ways. The necessary ingredient is that spreads have real effects that affect future default incentives. As in this paper, this transmission can be intermediated by policy: multiple equilibria are possible as long as the government undertakes some domestic policy action that (i) responds to current borrowing conditions, and (ii) affects its future repayment incentives, either directly or indirectly through the private sector. Examples of such policy are government reform effort, productive government spending, or taxation: actions that are costly today but increase the likelihood of higher growth tomorrow, or viceversa. Another possibility is that spreads affect real activity directly, for example through the banking sector. ${ }^{1}$ While I do not explore this mechanism here, I consider it a force that is complementary to the one analysed in this paper.

This paper mainly relates to two strands of the literature on sovereign debt and default. The first concerns equilibrium uniqueness and multiplicity in sovereign default models. As shown by Auclert and Rognlie (2016), the sovereign default framework in the tradition of Eaton and Gersovitz (1981), most common in the quantitative literature, features a unique equilibrium if debt is short-term. To analyse the role of beliefs, the literature on multiple equilibria relies on modifications of this framework along several dimensions. Calvo (1988) and subsequent work by Lorenzoni and Werning (2013) and Ayres et al. (2018) assume a different structure for the government debt auction, where the government fixes current auction revenues and future repayment obligations depend on debt prices, taken as given. In this framework, high interest rates imply high future debt, which makes default probabilities high and in turn justifies the high interest rates. Other papers, from the workhorse model of Cole and Kehoe (2000) to more recent work by Aguiar et al. (2016) and Conesa and Kehoe (2017), consider rollover risk by adopting a different timing assumption, whereby the government can issue new debt before deciding whether

\footnotetext{
${ }^{1}$ A large body of work examines the effect of government bond spreads on banks' balance sheets and private credit. See for example Bocola (2016), Arellano et al. (2017), Balke (2017) and Bottero et al. (2014).
} 
to default. Aguiar and Amador (2018) and Stangebye (2017) show that multiple equilibria may exist if the Eaton-Gersovitz model is extended to allow for long-term debt. Aguiar et al. (2015), Corsetti and Dedola (2016) and Bassetto and Galli (2017) analyse the interplay between selffulfilling beliefs and inflation, when debt is denominated in local currency. Bocola and Dovis (2016) evaluate quantitatively the contribution of fundamentals and beliefs in explaining the behaviour of government bond spreads. A feature common to all this literature is that it focuses solely on the interaction between government debt policy and bond spreads, assuming that output is exogenous. ${ }^{2}$

The second stream of literature relevant for this paper is that on sovereign default models with dynamic policy and endogenous output. ${ }^{3}$ Gordon and Guerron-Quintana (2018) and Bai and Zhang (2012) study quantitative models of default risk and capital accumulation that are similar to the framework presented in this paper. The crucial difference lies in their assumption that domestic policy is contractible, so debt prices do not affect investment but are rather a function of it. Müller et al. (2015) model domestic policy as effort to undertake structural reforms, which is assumed to have a separable cost and thus does not interact with lenders' beliefs in a way that creates the possibility of multiple equilibria. Broner et al. (2014) consider a model with capital and explore the possibility of belief-driven equilibria; in their model multiplicity is driven by a crowding-out effect of government debt on capital, and its interplay with creditor discrimination. Their mechanism is different and complementary to that analysed in this paper. Closest to my work is Detragiache (1996). She sketches a general framework where policy effort is non-contractible, has non-separable costs and positively affects future repayment probabilities; she observes that multiple equilibria are possible when lenders' coordination failure reduces lending and forces the government to provide less effort. My paper solidifies this intuition by characterising the equilibrium policy fully, relating it to notions of "fiscal austerity," exploring the implications of decentralising the equilibrium, and considering stable equilibria only.

\footnotetext{
${ }^{2}$ Cole and Kehoe (2000) do consider a model with capital, but there is no interaction between government fiscal policy and households' investment decisions.

${ }^{3}$ Arellano and Bai (2016) and Balke and Ravn (2016) also analyse sovereign default and fiscal policy in a model with endogenous output, but assume that both policy and production are static.
} 
This paper also relates to the literature on debt overhang and investment. Krugman (1988) and Sachs (1989) show that, when debt levels are high and taken as given, investment is discouraged because most of the return accrues to creditors. In Lamont (1995), corporate debt overhang can create complementarities in investment that generate multiple equilibria driven by expectations, in a way that is similar to the coordination problem among households that I also study. In more recent work, Aguiar et al. (2009) show that limited commitment on the side of the government leads to under-investment in bad times and when debt is large, as is true for equilibrium policy in this paper when creditors' expectations severely constrain borrowing.

The remainder of the paper proceeds as follows: Section 2 presents the two-period model; Section 3 illustrates the key mechanisms at play with a numerical example and characterises the equilibrium; Section 4 discusses some assumptions and alternative model specifications; Section 5 concludes. Appendix A presents a simplified, deterministic version of the two-period model that allows to derive closed-form results.

\section{Two-Period Model}

I consider a small open economy with a continuum of measure one of identical households and a government. Time is discrete and there are two periods, $t=0,1$.

The government is benevolent and wishes to maximise households' utility. It starts period 0 with a stock of debt due equal to $B_{0}$. It finances debt repayment by borrowing new oneperiod debt $B_{1}$ from international lenders, and collecting lump-sum taxes $T_{0}$. The government lacks a commitment technology, so in period 1 it can choose whether to repay or default on its debt coming due. In case of repayment, it collects lump-sum taxes $T_{1}$ from households. In case of default, it needs not tax, but households are assumed to suffer a random utility cost $\gamma$, distributed according to a cumulative distribution function $G(\gamma)$ with support $\Gamma \subseteq(0,+\infty){ }^{4}$ Following Lorenzoni and Werning (2013) I assume that initial debt $B_{0}$ cannot be defaulted upon

\footnotetext{
${ }^{4}$ The assumption that default has a direct utility cost is made for tractability and follows a large share of the literature.
} 
in period $0 .{ }^{5}$ The budget constraints of the government are given by

$$
\begin{aligned}
& B_{0}=T_{0}+q_{0} B_{1} \\
& \left(1-\delta_{1}\right) B_{1}=T_{1}
\end{aligned}
$$

where $\delta_{1}$ is a binary variable that takes the value of 1 if the government defaults, and 0 otherwise. Henceforth I will mention debt and tax policy interchangeably since either one pins down the other, conditional on debt price $q_{0}$ and initial debt level $B_{0}$. In Section 4 I argue that the results of the model are robust to two alternative assumptions: that default entails a proportional output cost, and that the government taxes production (or equivalently consumption) proportionally rather than in a lump-sum way. I choose lump-sum taxation because it isolates the new source of multiplicity in a transparent way.

Households have preferences represented by the utility function

$$
u\left(c_{0}\right)+\beta \mathbb{E}_{0}\left[u\left(c_{1}\right)-\delta_{1} \gamma\right]
$$

over individual consumption levels $\left\{c_{0}, c_{1}\right\}$, where $u\left(c_{t}\right):=c_{t}^{1-\eta} /(1-\eta)$ with $\eta>0$. They produce output using individual capital $k_{t}$ according to a concave production function $f\left(k_{t}\right):=k_{t}^{\alpha}$, and pay lump-sum taxes $T_{t}$ to the government. Households start with an initial stock of capital equal to $k_{0}$ and can only save through capital. For simplicity, I assume that capital fully depreciates over time, and that households produce using a backyard technology, the output of which they consume directly. ${ }^{6}$ The household budget constraints are given by

$$
\begin{aligned}
& c_{0}=f\left(k_{0}\right)-k_{1}-T_{0} \\
& c_{1}=f\left(k_{1}\right)-T_{1}
\end{aligned}
$$

where initial capital $k_{0}$ is given.

\footnotetext{
${ }^{5}$ Alteratively, I consider situations where the government has drawn a high realization of the default cost for period 0 and has thus chosen to repay $B_{0}$.

${ }^{6}$ Assuming instead that production is carried out by a representative firm that rents capital and hires labour (supplied inelastically) from households would deliver the same results, and would not affect the household coordination problem discussed later in Subsection 3.1.
} 
We can now examine the default decision of the government. Let us plug the government budget constraint at $t=1$ into that of the households, and denote aggregate capital in period $t$ with $K_{t}$. The optimal default decision solves

$$
\max _{\delta_{1}}\left\{\left(1-\delta_{1}\right) u\left[f\left(K_{1}\right)-B_{1}\right]+\left(1-\delta_{1}\right)\left(u\left[f\left(K_{1}\right)\right]-\gamma\right)\right\}
$$

It follows that the government defaults on its debt obligations if and only if the utility cost of defaulting is smaller than a threshold equal to the utility differential between default and repayment: ${ }^{7}$

$$
\gamma<\hat{\gamma}\left(K_{1}, B_{1}\right):=u\left[f\left(K_{1}\right)\right]-u\left[f\left(K_{1}\right)-B_{1}\right]
$$

When it is indifferent, I assume that the government chooses repayment. Importantly, default incentives are decreasing in output and increasing in debt, as is commonly assumed in the sovereign default literature.

I assume that households move after the government in period 0 . They take as given the quantity of debt issued and its price (and therefore tax policy), and form expectations about default in period 1 accordingly. This timing structure can be interpreted with the fact that private sector behaviour during the period between debt issuance and maturity affects the evolution of GDP and in turn the government default incentives at maturity. A key implication is that foreign lenders who price government debt must anticipate the response of the private sector to the outcome of the debt auction. ${ }^{8}$

We can now examine the household capital investment decision. As households are identical and have the same initial stock of capital, $k_{0}=K_{0}$. Let us replace first-period taxes $T_{0}$ with government net lending $B_{0}-q_{0} B_{1}$ inside the household budget constraint, and denote initial aggregate wealth with $W_{0}:=f\left(K_{0}\right)-B_{0}$. $W_{0}$ will be the relevant state variable for both the

\footnotetext{
${ }^{7}$ Under the assumption of log-utility we get the more intuitive condition that the government defaults if debt over GDP is larger than an increasing function of the default cost: $\frac{B_{1}}{f\left(K_{1}\right)}>1-e^{-\gamma}$.

${ }^{8}$ Bai and Zhang (2012) and Gordon and Guerron-Quintana (2018) instead assume that investment is contractible, which is equivalent to assuming households move first in my setting. This implies that capital is an argument of the price function for debt, which eliminates the scope for belief-driven multiple equilibria in the sovereign debt market.
} 
household and the government problem. Optimal individual investment solves

$$
\begin{aligned}
\max _{a_{1}} V\left(a_{1}, W_{0}, q_{0}, B_{1}, K_{1}\right) & :=u\left[W_{0}+q_{0} B_{1}-a_{1}\right]+\beta \int_{\hat{\gamma}\left(K_{1}, B_{1}\right)} u\left[f\left(a_{1}\right)-B_{1}\right] d G(\gamma) \\
& +\beta \int^{\hat{\gamma}\left(K_{1}, B_{1}\right)}\left\{u\left[f\left(a_{1}\right)\right]-\gamma\right\} d G(\gamma)
\end{aligned}
$$

and is thus a function of initial wealth $W_{0}$, government debt policy $B_{1}$, debt price $q_{0}$ and aggregate investment $K_{1}$. Solving (2) and imposing the symmetric equilibrium condition $a_{1}=K_{1}$ yields the aggregate private sector investment response function

$$
K_{1}^{*}\left(W_{0}, q_{0}, B_{1}\right):=\left\{K_{1}: K_{1} \in \arg \max _{a_{1}} V\left(a_{1}, W_{0}, q_{0}, B_{1}, K_{1}\right)\right\}
$$

In principle there could be multiple solutions to equation (2) due to complementarities in household investment, but in practice this will not be an issue, as explained in Section 3.1. Note that this coordination problem is separate, and independent of, the coordination problem among lenders.

Foreign lenders are risk-neutral and perfectly competitive. There is a continuum of them, of measure large enough that their aggregate lending capacity is never constrained. They are thus willing to buy any amount of debt as long as they make zero profits in expectation. The assumption that lenders are atomistic is crucial for the existence of complementarities in the debt issuance game. Lenders' discount factor is given by $\beta^{*}$, which needs not be equal to the households'. For simplicity, I assume that $B_{1}$ are discount bonds, which implies that the risk-free price of debt is equal to $\beta^{*}$.

A further assumption regarding the timing of the government debt auction is needed. Following most of the quantitative sovereign default literature, I adopt the timing structure of Eaton and Gersovitz (1981), whereby the government moves before lenders and chooses the quantity of debt it wishes to issue, and then lenders bid and determine the issuance price. It is well-known that, when output is exogenous and debt is short-term, this assumption generally leads to equilibrium uniqueness. ${ }^{9}$ A key point of this paper is that, if fiscal policy is non-contractible and

\footnotetext{
${ }^{9}$ For a discussion in both finite and infinite horizon settings, see Lorenzoni and Werning (2013), Ayres et al. (2018), Aguiar and Amador (2018), Auclert and Rognlie (2016) and Passadore and Xandri (2018).
} 
has real, dynamic effects on output, then multiple equilibria can arise in the Eaton-Gersovitz timing. ${ }^{10}$ The set of zero-profit prices at which lenders are willing to buy debt is given by

$$
Q\left(W_{0}, B_{1}\right)=\left\{q_{0}: q_{0}=\beta^{*} \operatorname{Prob}\left(\gamma \geq \hat{\gamma}\left[K_{1}^{*}\left(W_{0}, q_{0}, B_{1}\right), B_{1}\right]\right)\right\}
$$

Repayment probabilities depend on debt as well as investment. Private sector investment depends on debt auction revenues through a wealth effect on households in period 0: in order to repay initial debt $B_{0}$, the government must finance with taxes on households what it does not raise in sovereign debt markets. Because of this, there may exist multiple solutions to equation (4) for some $\left(W_{0}, B_{1}\right)$ pairs. This is the core source of multiple equilibria of the model, and will be examined more in detailed later.

I now define the notion of equilibrium, focusing on symmetric equilibria where all households take the same actions.

Definition 1. A competitive equilibrium is a collection of government debt and default choices $\left\{B_{1}, \delta_{1}\right\}$, households' investment choice $\left\{K_{1}\right\}$ and a debt price function $\left\{Q\left(W_{0}, B_{1}\right)\right\}$ such that, given initial wealth $W_{0}$,

1. households choose investment to maximise their expected utility, given government policies and debt prices;

2. the debt price function $Q\left(W_{0}, B_{1}\right)$ satisfies creditors' zero-profit condition for all debt levels $B_{1} \in \mathbb{R}$

3. government policies maximise households' expected utility, subject to the households' investment response and the debt price function.

I restrict the analysis to the set of initial wealth levels (i.e. initial $\left(K_{0}, B_{0}\right)$ pairs) such that the household budget set allows for positive consumption and investment levels.

Combining conditions (1), (2) and (4) we can focus on the government problem of choosing debt in period 0 to maximise households' utility, subject to its optimal default policy in period

\footnotetext{
${ }^{10}$ Section 4 discusses timing in the context of the existing literature more in detail.
} 
1, to creditors' zero-profit condition and to households' investment response:

$$
\begin{array}{rl}
\max _{B_{1}, q_{0}, K_{1}} & u\left(W_{0}+q_{0} B_{1}-K_{1}\right)+\beta\left[\int_{\hat{\gamma}\left(K_{1}, B_{1}\right)} u\left[f\left(K_{1}\right)-B_{1}\right] d G(\gamma)+\int^{\hat{\gamma}\left(K_{1}, B_{1}\right)}\left\{u\left[f\left(K_{1}\right)\right]-\gamma\right\} d G(\gamma)\right] \\
\text { s.t. } & q_{0}=q\left(W_{0}, B_{1}\right) \\
& K_{1}=k\left(W_{0}, q_{0}, B_{1}\right) \\
& W_{0} \text { given }
\end{array}
$$

where $q\left(W_{0}, B_{1}\right)$ and $k\left(W_{0}, q_{0}, B_{1}\right)$ are functions that arise from a selection from the correspondences $Q\left(W_{0}, B_{1}\right)$ and $K_{1}^{*}\left(W_{0}, q_{0}, B_{1}\right)$, and that the government takes as given.

\section{Multiplicity and Equilibrium Policy}

This section presents equilibrium policy and highlights the key mechanisms of the model laid out in the previous section. I derive optimality conditions and characterise the general features of equilibrium policy, while presenting a numerical example that shows the existence of multiple equilibria and their properties. In the appendix, I present a simpler version of the model that admits a complete, closed-form characterisation of the equilibrium. This choice is dictated by the fact that a closed-form solution can only be obtained by making a number of simplifying assumptions that eliminate interesting aspects of the model.

The analysis proceeds in three steps. First, I examine the private sector investment response. Second, I show that there may exist multiple zero-profit prices consistent with the same level of debt issuance. I show under what conditions this happens, and I adopt a selection criterion that determines the prices on which lenders coordinate, considering only stable solutions. Third, I analyse the government optimal policy, and show that multiple equilibria exist where policy depends on the debt price schedule faced by the government.

In the parametric example I assume the following: capital share of output $\alpha=0.4$, riskaversion parameter $\eta=1$ (log-utility), households' and lenders' discount factor $\beta=\beta^{*}=0.97$, default utility cost log-normally distributed with mean 0.25 , standard deviation 0.25 and support 
truncated to the interval $\Gamma=[0.1,4]$.

\subsection{Private Sector Investment Response}

I start by considering households' investment decision conditional on government debt issuance $B_{1}$ and debt price $q_{0}$ (or, equivalently, tax policy $T_{0}$ ). Households take future default and tax policy as given because they are atomistic, so they do not internalise the effects of their choice on aggregate investment. The individual best response $a_{1}^{*}\left(K_{1}\right)$ to aggregate investment $K_{1}$ solves the household investment problem in (2) and is given by the following first-order condition

$$
u^{\prime}\left(W_{0}+q_{0} B_{1}-a_{1}\right)=\beta f^{\prime}\left(a_{1}\right)\left\{\left[1-G\left(\hat{\gamma}\left(K_{1}, B_{1}\right)\right)\right] u^{\prime}\left[f\left(a_{1}\right)-B_{1}\right]+G\left(\hat{\gamma}\left(K_{1}, B_{1}\right)\right) u^{\prime}\left[f\left(a_{1}\right)\right]\right\}
$$

For a given $\left(W_{0}, q_{0}, B_{1}\right)$ triplet, there may in principle exist multiple fixed point solutions $a_{1}^{*}\left(K_{1}\right)=K_{1}$ to equation (6), because of complementarities in household investment. In practice, however, various numerical explorations suggest that only in rare cases equation (6) does admit multiple solutions, and that this multiplicity has negligible implications for the purpose of characterising the equilibrium. The mechanism is still worth inspecting in detail here, because the forces driving it play a role in the analysis that follows.

Equation (6) highlights the role of aggregate capital, and in turn of default probabilities. Future default discourages private investment, because by reneging on its debt obligations the government does not have to tax households in period 1, and this generates a positive wealth effect that reduces households' incentive to invest. Suppose that households expect aggregate investment $K_{1}$ to be low, and therefore default to be likely. This means that they do not expect to pay taxes in period 1 , which renders their future marginal utility and their saving motive relatively low. The opposite happens if households expect $K_{1}$ to be high instead. It follows that, for a given $\left(W_{0}, q_{0}, B_{1}\right)$ triplet, complementarities among households may in principle yield multiple solutions to (6). ${ }^{11}$ Complementarities are stronger (i) when period-0 taxes are high and wealth is low, since the marginal utility differential between default and repayment states is

\footnotetext{
${ }^{11}$ This logic is analogous to that in the sovereign debt application of Bassetto (2005). There too a future default discourages production, and there exist complementarities in private production decisions that may generate multiple equilibria.
} 
decreasing in invested capital; and (ii) in the limiting case where the distribution of the utility cost $\gamma$ has a variance close to zero, so that a marginal change in aggregate capital around the mode of the distribution causes a sharp increase in the marginal benefit of individual capital investment. In Appendix A I show how an alternative assumption about the structure of taxes in period 1 can unambiguously eliminate the issue.

\subsection{Debt Price Schedules}

I now examine creditors' zero-profit condition: for a given level of debt issuance $B_{1}$ and initial wealth $W_{0}$, I consider whether there exist multiple zero-profit prices that solve equation (4). Earlier, I analysed private sector investment keeping government policy (debt and taxes) and debt prices fixed. There, the anticipation of default or repayment had an effect on households' wealth in the second period. Now I go backwards in the order of play within the first period, and I consider how a change in the price of debt affects private investment. This approach is consistent with the timing of the government debt auction: lenders bid a price after the government has chosen how much debt to issue, anticipating the effect of debt auction revenues on government tax policy, and in turn on households' wealth, in the first period.

The right panel of Figure 1 plots private sector aggregate investment $K_{1}^{*}\left(W_{0}, q_{0}, B_{1}\right)$ as a function of the price of debt $q_{0}$, for three different levels of debt issuance $B_{1}$. The left panel plots the right-hand side of equation (4) (that is, repayment probabilities adjusted by lenders' discount factor $\beta^{*}$ ) as a function of $q_{0}$, for the same three debt levels. Zero-profit prices are represented by markers and correspond to the points where the curves intersect the 45-degree dotted line.

Let us focus on the aggregate investment response first, as determined by condition (6) after imposing the equilibrium condition $a_{1}=K_{1}$. As explained in the previous subsection, the marginal benefit of investment is given by the average of marginal utilities in default and repayment states, weighted by the probability of each. Consider for now the curves that correspond to an intermediate level of $B_{1}$, depicted in red. Investment is always increasing in $q_{0}$, because larger debt prices imply more available resources in period 0 , reducing the marginal utility of consumption in period 0 and thus the marginal cost of investing extra resources. When $q_{0}$ is 

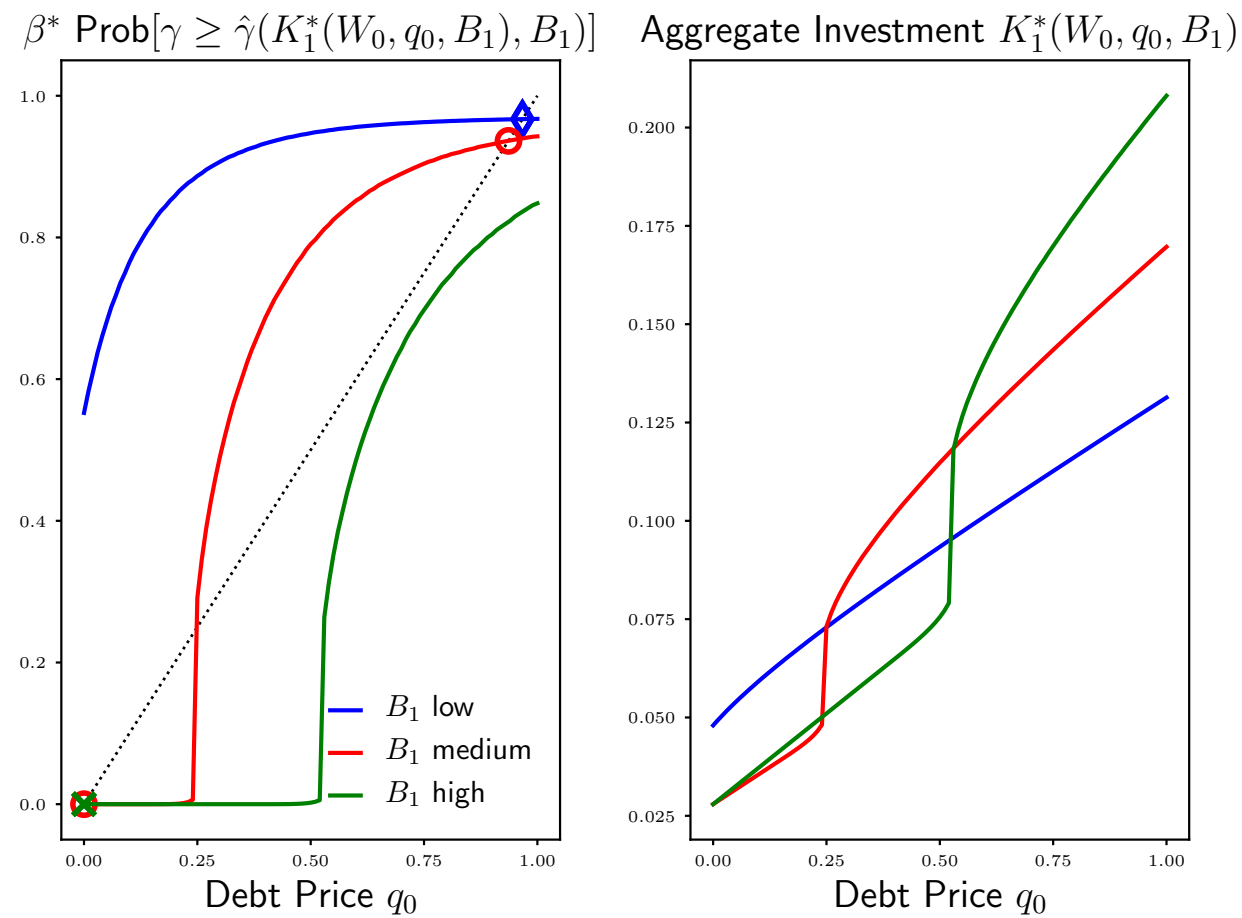

Figure 1: Example of zero-profit prices (left-hand side) and capital investment (right-hand side) as a function of $q_{0}$, given $W_{0}$.

low, so are revenues from the government debt auction, which force the government to increase period-0 taxes. This negative effect on household wealth in $t=0$ depresses investment to a level that makes default likely; high default probabilities reinforce this mechanism by also pushing down the motive to invest. ${ }^{12}$ In this scenario (represented by values of $q_{0}$ roughly below 0.25 in the figure) investment is a constant fraction of households' after-tax wealth, because the log-utility assumption implies income and substitution effects cancel out exactly. As the price of debt increases, so does invested capital, and repayment probabilities eventually move away from zero. This results in a sharp increase in the marginal benefit of saving, because marginal utility is larger under repayment, when households pay taxes in period 1 too. This produces the non-linear increase in investment visible in the right panel of Figure 1, which corresponds to the sharp positive jump in repayment probabilities. Larger debt prices are thus associated with

\footnotetext{
${ }^{12}$ The effect of default expectations on investment incentives is discussed in detail in the previous subsection, and is not essential for the multiplicity result.
} 
a stronger investment motive: lower taxes increase households' wealth in $t=0$, while higher repayment probabilities reinforce the motive to save by increasing its marginal benefit.

This mechanism does depend on the shape of the default cost distribution and on the curvature of the utility function. The lower is the distribution variance, the less smooth will be the behaviour of private investment to changes in the price of debt, and the wider the range of debt levels for which there exist multiple zero-profit prices. ${ }^{13}$ The role of utility curvature is more complex because it is composed by two counteracting forces. More utility curvature makes taxes in period 1 more painful: on one hand, this means that repayment probabilities are lower when consumption under repayment is close to zero, because default is more attractive; on the other hand, higher curvature implies that the marginal utility differential between repayment and default states is larger. Under this specification of the model, the first effect dominates the second, so more curvature implies a smoother response of $K_{1}^{*}$ to $q_{0}$.

When debt belongs to an intermediate region, the joint effect of all these forces determines the existence of multiple zero-profit prices. When instead issued debt is large (small), as indicated by the green (blue) curves in Figure 1, there exists only one zero-profit price close to zero (one). The rationale is that, when debt is either low or high, the effect of debt prices on period-0 household wealth is not strong enough to generate the non-linear response of investment just examined.

Figure 2 represents an example of the debt price function $Q\left(W_{0}, B_{1}\right)$ for a given level of initial wealth $W_{0}$, which is the result of repeating the previous analysis for all possible levels of government debt issuance. Ignoring the colouring, we can see that the set of zero-profit prices is given by an inverted-S curve, and the function $Q\left(W_{0}, B_{1}\right)$ is a correspondence that maps from debt levels $B_{1}$ into a set of debt prices in the $\left[0, \beta^{*}\right]$ interval. If the government issues a low (high) amount of debt, it will be certain to get a price close to one (zero) for it, because that is the only price consistent with creditors' zero-profit condition. If instead the government issues an amount of debt inside what I call the "multiplicity region", represented in the figure by all intermediate debt levels inside the $\left[\underline{B}_{1}, \bar{B}_{1}\right]$ interval, it may get either of the three zero-profit prices consistent with it.

\footnotetext{
${ }^{13}$ See the model of Appendix A for an example where the role of the default cost distribution can be analysed even more accurately, since the investment response is independent of it.
} 


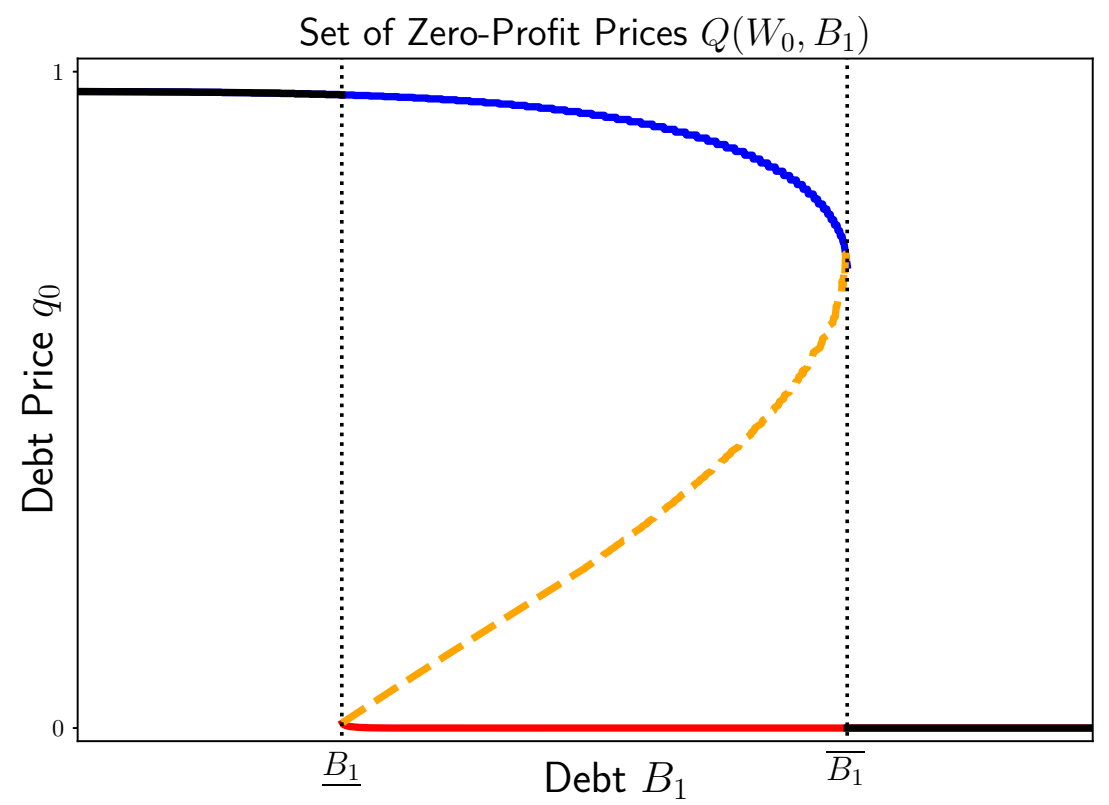

Figure 2: Example of debt price function $Q\left(W_{0}, B_{1}\right)$, for a given initial wealth $W_{0}$.

\subsection{Timing and Creditors Coordination}

From now on, I split the correspondence $Q\left(W_{0}, B_{1}\right)$ into single-valued schedules. Let us first note that, for all debt levels outside the multiplicity region, $Q\left(W_{0}, B_{1}\right)$ is single-valued. This will be the "common" part of any schedule, depicted in solid black in Figure 2. I define as the "good" schedule $Q_{g}\left(W_{0}, B_{1}\right)$ the function composed by the upper envelope of curve in the multiplicity region (in solid blue), together with the common part. This curve will thus feature a discontinuity at $\bar{B}_{1}$, where in the example the price of debt jumps from a price close to 0.7 to one equal to zero. Similarly, I define as the "bad" schedule $Q_{b}\left(W_{0}, B_{1}\right)$ the function composed by the lower envelope of the curve in the multiplicity region (in solid red), together with the common part. Lastly, note that the dashed orange part of the curve inside the multiplicity region is unstable, in the sense that it is upward sloping. If the government were restricted to choose a point in that subset of the correspondence, it would always choose the largest possible debt level because that would fetch the highest price. For this reason I ignore such part of the debt price correspondence in the analysis. ${ }^{14}$

\footnotetext{
${ }^{14}$ Lorenzoni and Werning (2013) and Ayres et al. (2018) also do not consider equilibria in the unstable part of their debt price schedules, and show the existence of multiple stable equilibria assuming long-term debt or
} 
This criterion to discipline coordination among lenders minimizes the number of discontinuities in each of the price schedules, and offers a clear ranking of schedules from the point of view of the government-borrower. In this example, I choose the two points of discontinuity that coincide with the boundaries of the multiplicity region. ${ }^{15}$

Finally, I assume that at the beginning of period 0, the government knows which price schedule it will face when it issues new debt $B_{1}$. The rationale behind this assumption is that, before auctioning off new debt, an issuer can observe conditions in the secondary market and understand ex ante at what price it may be able to issue a certain amount of debt. I thus interpret situations in which the government is facing the bad schedule as debt crises, or periods of market turbulence such as the European debt crisis, where sovereign borrowing becomes more difficult and investors are particularly concerned with default risk. In such times the government realises that, if it were to issue a level of debt inside the multiplicity region, it would raise little funds because lenders would coordinate on the bad schedule.

\subsection{Government Policy and Equilibria}

So far, I have shown that the conditions at which the government is borrowing new debt may depend on self-fulfilling beliefs on the side of creditors. The existence of multiple outcomes of the issuance games, i.e. of multiple price schedules, is however a necessary but not sufficient condition for the existence of multiple equilibria. To have the latter, it is also necessary that debt policy indeed depends on which price schedule the government is facing. That is, since the government has the advantage of moving first and choosing the optimal amount of debt to issue, equilibrium tax and debt policies will be a function of creditors' beliefs insofar as the borrowing motive is strong enough to push the government to consider debt levels inside the region that

bimodal output distributions. This paper thus proposes an alternative mechanism that also delivers multiple stable equilibria, and does so in the Eaton and Gersovitz (1981) timing.

${ }^{15}$ Other pairs of price schedules obtained choosing any two discontinuity points inside the multiplicity region would also satisfy the above-mentioned properties. I pick the two boundaries to make my point more starkly. Other criteria with more than one discontinuity are less compelling, because they would make the price locally increasing in debt issuance. 
features multiple debt prices.

I now characterize government debt policy and households' investment policy as a function of the initial state $W_{0}$ and the debt price schedule $\left\{Q_{i}\left(W_{0}, B_{1}\right)\right\}_{i=\{g, b\}}$. At any interior point where $Q_{i}\left(W_{0}, B_{1}\right)$ is differentiable, the optimality condition for government debt is given by

$$
u^{\prime}\left(c_{0}\right)=\frac{\beta}{Q_{i}\left(W_{0}, B_{1}\right)+B_{1} \frac{\partial Q_{i}\left(W_{0}, B_{1}\right)}{\partial B_{1}}} u^{\prime}\left[f\left(K_{1}\right)-B_{1}\right]\left[1-G\left(\hat{\gamma}\left(K_{1}, B_{1}\right)\right)\right]
$$

which I obtain after taking the first-order condition of government problem (5) with respect to $B_{1}$, and plugging it in equation (6). Equation (7) shows that the rate of return on debt is the inverse of the marginal revenue from borrowing one additional unit. As is standard in sovereign default models, $B_{1} \frac{\partial Q_{i}\left(W_{0}, B_{1}\right)}{\partial B_{1}}$ represents the negative price effect of issuing an additional unit of debt. Combining (7) with (6) yields

$$
\begin{aligned}
& f^{\prime}\left(K_{1}\right) u^{\prime}\left[f\left(K_{1}\right)\right] G\left(\hat{\gamma}\left(K_{1}, B_{1}\right)\right) \\
& =\left(\frac{1}{Q_{i}\left(W_{0}, B_{1}\right)+B_{1} \frac{\partial Q_{i}\left(W_{0}, B_{1}\right)}{\partial B_{1}}}-f^{\prime}\left(K_{1}\right)\right) u^{\prime}\left[f\left(K_{1}\right)-B_{1}\right]\left[1-G\left(\hat{\gamma}\left(K_{1}, B_{1}\right)\right)\right] .
\end{aligned}
$$

In equilibrium, the difference between the marginal interest paid on debt and the marginal product of capital must be positive, since investment pays off in both repayment and default states while debt does not.

The following proposition further characterises equilibrium policy (the formal proof can be found in the appendix).

Proposition 1 (Risk-free and risky policy).

1. Policy is risk-free and is given by a government borrowing function $B_{1}^{f}\left(W_{0}\right)$ and a household constant investment level $K_{1}^{f}$ such that

$$
f^{\prime}\left(K_{1}^{f}\right)=\frac{1}{\beta^{*}} ; \quad B_{1}^{f}\left(W_{0}\right)=\frac{f\left(K_{1}^{f}\right)-\frac{\beta}{\beta^{*}}\left(W_{0}-K_{1}^{f}\right)}{1+\beta}
$$

for all $W_{0} \geq W_{0}^{f}$, where $W_{0}^{f}:=K^{f}+\frac{\beta^{*}}{\beta} f\left(K^{f}\right)\left[1-(1+\beta)\left(1-e^{-\inf (\Gamma)}\right)\right]$.

2. For all $W_{0}<W_{0}^{f}$, government and household policy are such that debt is risky and capital investment is below the risk-free level:

$$
K_{1}<K_{1}^{f} ; \quad Q_{i}\left(W_{0}, B_{1}\right)<\beta^{*} \quad \forall i \in\{b, g\} .
$$


Note that the separation of the state-space in two regions that feature distinct equilibrium policy is a general result that is independent of the parametrization of the model. It is however difficult to prove formally whether risky policy does involve debt levels in the multiplicity region of the debt price schedules. For this, I consider the following results from the numeric example introduced earlier.
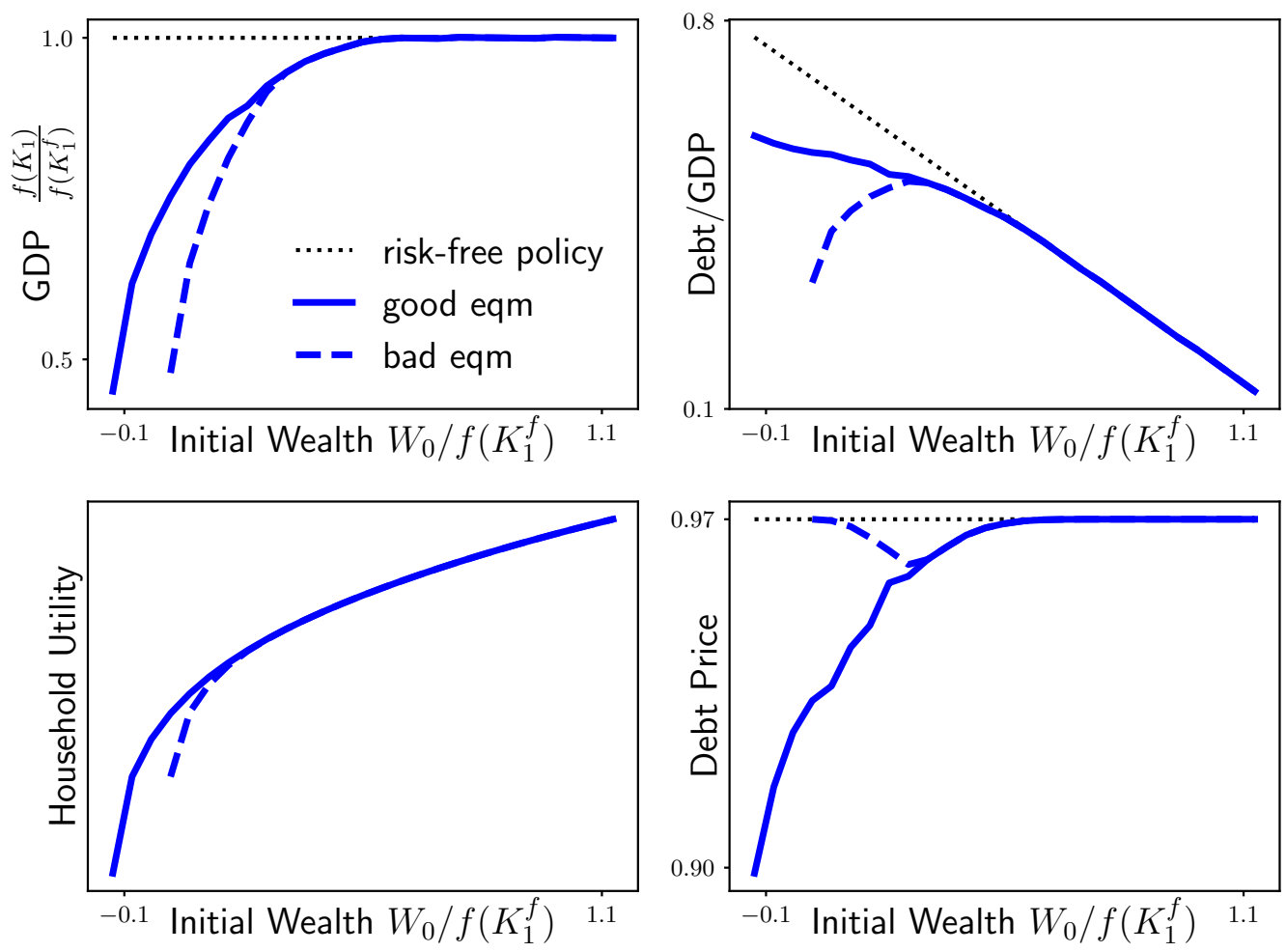

Figure 3: Policy functions, household utility and equilibrium debt prices, as a function of initial wealth $W_{0}$ scaled by GDP under the risk-free policy $f\left(K_{1}^{f}\right)$.

Figure 3 plots actual GDP $f\left(K_{1}\right)$ (as a ratio to risk-free GDP $f\left(K_{1}^{f}\right)$ ), government debt policy (as a ratio to actual GDP), household utility and equilibrium debt prices as a function of initial wealth. Dashed lines denote the bad equilibrium, which I interpret with a debt crisis where lenders' beliefs are pessimistic; solid lines denote the good equilibrium where borrowing conditions are favourable. All curves are truncated at the initial wealth level where the equilibria stop existing because positive consumption is not possible anymore. 
When initial wealth is sufficiently large, government and households policy is risk-free: ${ }^{16}$ it is unaffected by the problem of lack of commitment, repayment is certain, capital investment is constant at $K_{1}^{f}$ and the net interest paid on debt (or earned on savings) is $1 / \beta^{*}$.

For lower levels of wealth, policy is risky: it is constrained by the risk of default, the net interest paid on debt is positive and capital investment is below its risk-free level. The economic intuition behind risky policy is the following: when wealth is low, the desire to front-load consumption is strong enough to make risky debt preferable to risk-free debt, even if that comes at a higher cost due to the presence of a default risk premium; in turn, costlier borrowing lowers the incentive to invest in capital as its opportunity cost rises. When wealth is at an intermediate level, however, the borrowing motive is not strong enough to push debt issuance in the multiplicity region, and policy is unaffected by lenders' beliefs.

When instead initial wealth becomes sufficiently low, it enters a region where equilibrium policy does change depending on debt market conditions. Under the good schedule, the government keeps borrowing relatively large amounts of debt. While the stock of newly issued debt does decrease as wealth becomes lower, the debt/GDP ratio remains high and actually increases, due to lower investment which makes output drop at a faster rate. Under the bad schedule, which I interpret as a confidence crisis, issuing too much debt becomes prohibitively costly (i.e. debt prices would belong to the red part of the price schedule of Figure 2) because lenders hold pessimistic beliefs about the behaviour of the private sector. The government effectively becomes debt constrained, and is forced to reduce external borrowing and increase domestic taxation, thereby reducing debt/GDP ratios while depressing private consumption and investment. Because the constraint on borrowing is tighter, positive consumption and investment under the bad equilibrium stop being feasible at larger levels of wealth than under the good equilibrium.

The set of policies under the bad equilibrium can be seen as part of the so-called "fiscal austerity" policy recommendations that were at the centre of the debate during the European debt crisis. The bad equilibrium is thus an example of a situation where government debt markets are in turmoil, pessimistic beliefs are self-fulfilling, and austerity policies that bring

\footnotetext{
${ }^{16}$ Black dotted lines represent what risk-free policy would look like if it were feasible for any level of initial wealth.
} 
down debt/GDP ratios are optimal in the face of prohibitively high borrowing costs, although they are accompanied by lower output growth and especially lower domestic welfare.

The example thus shows that there exist multiple equilibria in the debt issuance game between foreign lenders and the government. This result is driven by two factors: first, the way in which the government mixes debt and tax policy as a function of borrowing conditions; second, the effect of tax policy on private investment. In bad times, when lenders are pessimistic and fail to coordinate on good debt prices, the government is forced to adjust to adverse borrowing conditions by substituting debt with taxes: these impact households' wealth in the first-period, depressing investment and output.

\section{Discussion of Assumptions}

The current specification of the model was chosen because it is the most transparent way of presenting the mechanisms behind equilibrium multiplicity. However, the result is robust to a number of alternative assumptions that I now illustrate in detail.

First, taxation is assumed to be lump-sum. In period 0 this is obviously an innocuous assumption, while in period 1 it changes the optimality condition for investment. Assuming a proportional tax on production ${ }^{17}$ creates an externality that reduces the marginal product of capital in repayment states, working against the wealth effect of taxation in period 1 . This dampens the non-linearity of the private sector investment response to the price of debt, and eliminates the potential issue of coordination failure among households highlighted in Subsection 3.1. In Appendix A I show that this modification does not affect my results significantly, ${ }^{18}$ but proves convenient for closed-form derivations.

Second, default costs are assumed to be direct utility costs. This is a simplification that makes the exposition particularly clean, especially with respect to the analysis of the private sector investment response. An alternative would be to assume that in case of default the

\footnotetext{
${ }^{17}$ This would be analogous to assuming taxes on income from capital or labour in a representative firm setting.

${ }^{18}$ The crucial driver of multiplicity in the model is the wealth effect that debt prices have in period 0 through taxation, not the wealth effects of default or taxation in period 1.
} 
economy suffers a production loss equal to a random share of output. ${ }^{19}$ This would have a different interpretation, linked to a large area of the literature where defaults are shown to cause production losses due, for example, to disruptions in access to foreign inputs and in the domestic banking sector. However, it would not change the structure of default incentives, that would still be increasing in debt and decreasing in output, nor would it affect the existence and features of equilibrium multiplicity. The non-linearity in the investment response highlighted in Subsection 3.2 would be largely unchanged: the difference in the marginal benefit of investment between repayment and default states would come from differences in the marginal product of capital rather than in the marginal utility of second-period consumption. In fact, in the special case of log utility adopted in the example, the first-order condition for investment in equation (6) would be identical across the two specifications.

Finally, I make two timing assumptions that are crucial for the results of the model. First, I assume that the structure of the government debt auction follows the Eaton-Gersovitz timing. As Lorenzoni and Werning (2013) carefully point out, this assumption implies that the government implicitly commits to adjust taxes or spending in order to satisfy the budget constraint, in case debt prices were different than expected. ${ }^{20}$ They argue that it would be more plausible to assume that, in the short term, the margin that adjusts is debt policy rather than fiscal policy. Second, I assume that the private sector moves after the government, because I want to study how private investment responds to fiscal policy. These two assumptions are a reduced form way to represent more complex and realistic environments, where debt is long-term and the state variables affecting the future incentives to default are determined after debt issuance and are not contractible. On one hand, I interpret the length of a period in my paper as long enough to allow a deterioration in government borrowing conditions to feed through to tax policy and to private investment. On the other hand, the assumption of Lorenzoni and Werning (2013) that the government takes debt prices and current fiscal policy as given would render the model a

\footnotetext{
${ }^{19}$ This would be analogous to assuming that the productivity of capital is random, and the cost of default is a fixed share of output.

${ }^{20}$ For a detailed discussion of the implication of different assumptions regarding the timing and structure of the government debt auction, see also Ayres et al. (2018).
} 
version of Calvo (1988) with capital, changing the nature of multiplicity but not its existence.

\section{Conclusion}

Default risk is the key determinant of sovereign borrowing costs, which have important implications for the joint dynamics of debt and fiscal policy, especially in countries with weak fundamentals and high stocks of debt and over the medium term. This paper models in a simple and tractable way the circular relationship between government bond spreads, fiscal and debt policy, and economic activity.

I find that, under certain conditions, the expectations of sovereign debt investors may be self-fulfilling and, in a confidence crisis, induce a government to follow austerity policies that reduce debt levels at the cost of depressed output and consumption. I believe that this can be an interpretation of the dynamics of southern European countries during the European debt crisis of 2010-12, and may be a useful framework for the analysis of scenarios where turbulent conditions in sovereign debt markets condition debt and fiscal policy in meaningful ways.

This paper studies a specific channel through which sovereign credit risk affects economic activity with a negative feedback loop. The next step in this analysis would be to embed this multiplicity channel in a quantitative model and contrast it with others that have been emphasized in previous work.

Another direction for future work is to study the policy implications of my results. Because multiplicity arises from the fact that lenders are atomistic and may coordinate on bond prices that are bad for the government, promoting lenders' coordination through institutions in the spirit of the London Club would help to solve the problem, without the need to resort to bilateral official lending with attached conditionality.

\section{Appendix A Two-Period Model without Uncertainty}

Here I present a two-period model with proportional taxes in $t=1$. For now I continue to assume that the default cost is random as in the main text; later on I will consider the limiting 
case where the variance of the default cost distribution goes to zero, in order to draw sharper analytical conclusions. The government budget constraint in $t=1$ now reads

$$
\left(1-\delta_{1}\right) B_{1}=\tau_{1} f\left(K_{1}\right)
$$

where $\tau_{1}$ is a proportional tax on production that equals $B_{1} / f\left(K_{1}\right)$ in case of repayment and zero in case of default. The default cutoff of the government remains identical to (1). What changes is the individual investment problem: there is now an externality, given by the proportional tax in repayment states, that reduces the marginal product of capital. The first-order condition for individual capital investment $a_{1}$ is given by

$$
\begin{aligned}
u^{\prime}\left(W_{0}+q_{0} B_{1}-a_{1}\right)=\beta f^{\prime}\left(a_{1}\right)\{ & {\left[1-G\left(\hat{\gamma}\left(K_{1}, B_{1}\right)\right)\right]\left(1-\tau\left(K_{1}, B_{1}\right)\right) u^{\prime}\left[f\left(a_{1}\right)\left(1-\tau\left(K_{1}, B_{1}\right)\right)\right] } \\
& \left.+G\left(\hat{\gamma}\left(K_{1}, B_{1}\right)\right) u^{\prime}\left[f\left(a_{1}\right)\right]\right\} .
\end{aligned}
$$

This illustrates how the proportional tax assumption dampens the sources of household coordination failure highlighted in Subsection 3.1: the marginal product of capital under repayment is now smaller than under default, and this largely offsets the marginal utility differential between states. Under the assumption of log-utility, the two differentials cancel out exactly and, after imposing the equilibrium condition $a_{1}=K_{1}$, we get that private sector aggregate investment is a constant fraction of after-tax household wealth in $t=0$

$$
K_{1}^{*}\left(W_{0}, q_{0}, B_{1}\right)=\frac{\alpha \beta}{1+\alpha \beta}\left(W_{0}+q_{0} B_{1}\right)
$$

This result holds true regardless of the probability of default, making the model more tractable and highlighting the independent role of the default cost distribution in determining repayment probabilities. In fact, plugging equation (12) into (4) we get that the set of zero-profit prices is given by

$$
Q\left(W_{0}, B_{1}\right)=\left\{q_{0}: q_{0}=\beta^{*} \operatorname{Prob}\left(\gamma \geq \log \left[1-\frac{B_{1}}{f\left(\frac{\alpha \beta}{1+\alpha \beta}\left(W_{0}+q_{0} B_{1}\right)\right)}\right]^{-1}\right)\right\}
$$

As is clear from the right-hand side of the zero-profit condition, the default cutoff is a function of $\left(W_{0}, q_{0}, B_{1}\right)$ only and is independent of the structure of $G(\gamma)$. The effect of debt price variations on repayment probabilities is thus all due to the specifics of the distribution. Figure 4 

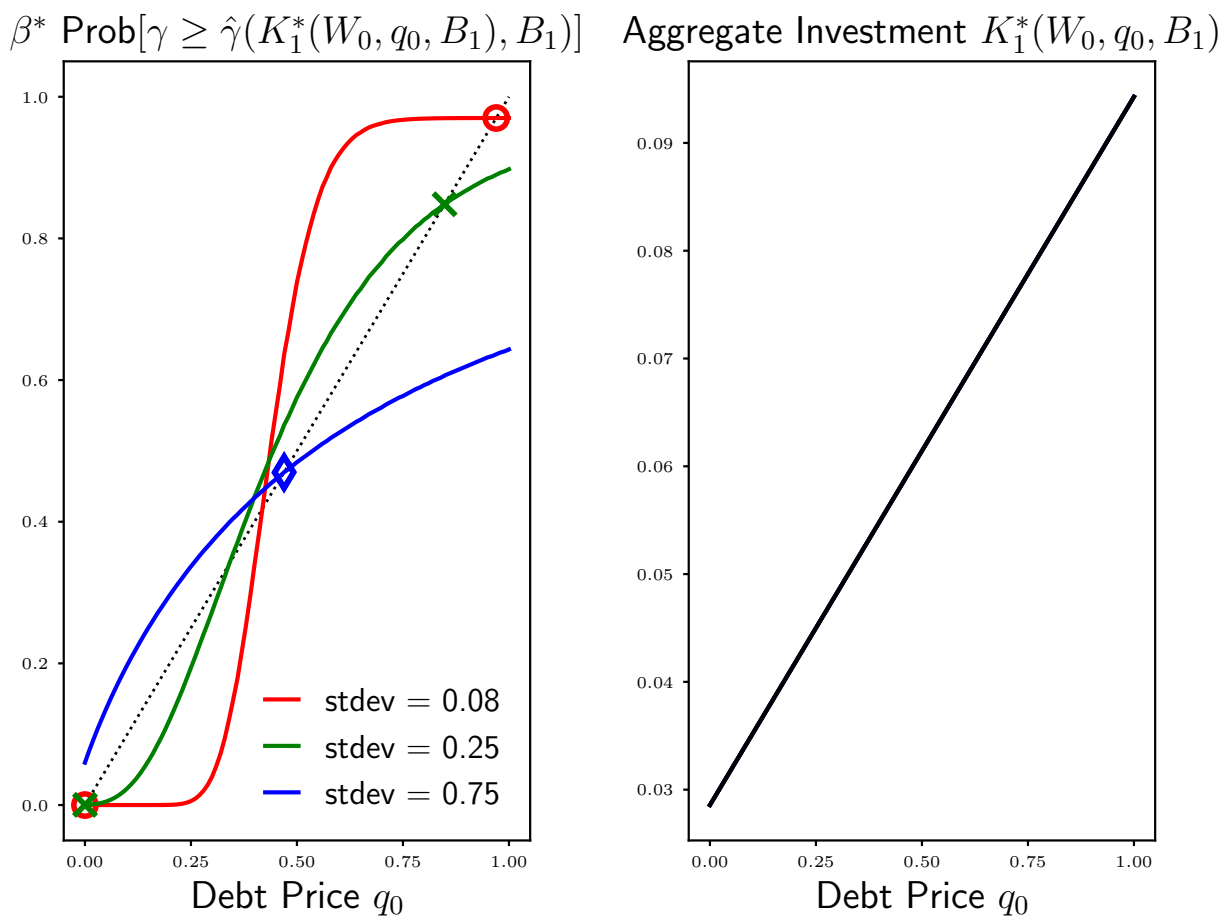

Figure 4: Zero-profit prices (left-hand side) and capital investment (right-hand side) as a function of $q_{0}$, given $B_{1}$ and $W_{0}$.

plots repayment probabilities and investment responses for different standard deviations of the distribution $G$, keeping all other parameters equal to those of the numerical example in the main text. The right panel only shows one curve coloured in black, to represent the fact that the investment response is independent of the default cost variance. What affects the shape of the repayment probability curves in the left panel, and is a key driver of the existence of belief-driven multiple equilibria in this setting, is that the default cost distribution has an interior mode and is not too dispersed, a criterion satisfied by most bell-shaped distributions.

No Uncertainty. I now consider the limiting case where the distribution $G$ is degenerate with all probability mass at a single point $\bar{\gamma}>0$, which allows to proceed with analytical derivations. Let us denote with

$$
\bar{K}_{1}\left(B_{1}\right):=\left(\frac{B_{1}}{1-e^{-\bar{\gamma}}}\right)^{1 / \alpha}
$$


the threshold for private investment above (below) which the government finds it optimal to repay (default on) its debt $B_{1}$. A sufficient condition for the existence of multiple zero-profit prices is that, for a given $\left(W_{0}, B_{1}\right)$ pair, the following two conditions on investment are verified simultaneously:

$$
K_{1}^{*}\left(W_{0}, 0, B_{1}\right)<\bar{K}_{1}\left(B_{1}\right) \wedge K_{1}^{*}\left(W_{0}, \beta^{*}, B_{1}\right) \geq \bar{K}_{1}\left(B_{1}\right)
$$

This simply means that, if the government cannot borrow a certain amount of debt because creditors anticipate it will default on it, taxes in period 0 will be high and private investment will indeed be below the repayment threshold; viceversa, if the government can borrow at the risk-free rate because creditors anticipate repayment, taxes will be low and private investment will be above the repayment threshold. It can be proved that, for any non-negative initial wealth level, there always exists a non-empty interval of debt levels such that the conditions of (14) are verified. I denote with $\underline{B}_{1}\left(W_{0}\right)<\bar{B}_{1}\left(W_{0}\right)$ the lower and upper bounds of such interval. ${ }^{21}$ Note that both borrowing limits are increasing in initial wealth $W_{0}$.

As in the main text, I define the "good" schedule as that under which the government can borrow risk-free up to $\bar{B}_{1}\left(W_{0}\right)$, and the "bad" schedule as the one that limits risk-free borrowing to $\underline{B}_{1}\left(W_{0}\right)$.

We can now move on to characterise the government optimal debt policy. The features of equilibrium policy are analogous to those derived in the main text, except that the absence of uncertainty here implies debt is always risk-free. When the borrowing limit is not binding, debt policy is unconstrained and is given by the solution for $B_{1}$ to the equation

$$
B_{1}=\frac{f\left(K_{1}^{*}\left(W_{0}, \beta^{*}, B_{1}\right)\right)-\frac{\beta}{\beta^{*}}\left[W_{0}-K_{1}^{*}\left(W_{0}, \beta^{*}, B_{1}\right)\right]}{1+\beta} .
$$

When it is feasible, government and households follow the unconstrained policy of (15), which I denote with $B_{1}^{u}\left(W_{0}\right)$. The following proposition characterises equilibrium debt policy exactly.

Proposition 2. Let us denote with $\underline{W}_{0}<\bar{W}_{0}$ the initial wealth levels such that $B_{1}^{u}\left(\overline{W_{0}}\right)=$ $\underline{B}_{1}\left(\bar{W}_{0}\right)$ and $B_{1}^{u}\left(\underline{W}_{0}\right)=\bar{B}_{1}\left(\underline{W}_{0}\right)$.

\footnotetext{
${ }^{21}$ The first condition of (14) is equivalent to $B_{1}^{1 / \alpha}>\frac{\alpha \beta\left(1-e^{-\bar{\gamma}}\right)^{1 / \alpha}}{1+\alpha \beta} W_{0}$. The second condition of (14) is equivalent to $B_{1}^{1 / \alpha} \leq \frac{\alpha \beta\left(1-e^{-\bar{\gamma}}\right)^{1 / \alpha}}{1+\alpha \beta} W_{0}+\frac{\alpha \beta\left(1-e^{-\bar{\gamma}}\right)^{1 / \alpha}}{1+\alpha \beta} B_{1}$.
} 
1. Under the bad schedule, equilibrium policy is given by

$$
\left\{\begin{array}{l}
B_{1}^{u}\left(W_{0}\right) \text { for } W_{0}>\bar{W}_{0} \\
\underline{B}_{1}\left(W_{0}\right) \text { for } W_{0} \leq \bar{W}_{0} .
\end{array}\right.
$$

2. Under the good schedule, equilibrium policy is given by

$$
\left\{\begin{array}{l}
B_{1}^{u}\left(W_{0}\right) \text { for } W_{0} \geq \underline{W}_{0} \\
\bar{B}_{1}\left(W_{0}\right) \text { for } W_{0}<\underline{W}_{0} .
\end{array}\right.
$$

In words, when the government faces the bad schedule it can follow the unconstrained policy for a smaller range of wealth states than under the good schedule, and the risk-free borrowing limit starts binding at a larger level of initial wealth. Additionally, constrained policy under the good schedule is characterised by a looser borrowing limit, that permits a larger level of borrowing, investment and household welfare.

\section{Appendix B Proofs}

Proof of Proposition 1. First I prove statement 2, i.e. that when debt policy is risky capital investment is below its risk-free level $K_{1}^{f}$. Let us start by noting that capital can never be above the risk-free level because its marginal return would be inferior to that of risk-free debt, in which case it would be optimal for the government to save using debt rather than capital. Let $C_{1}^{R}$ and $C_{1}^{D}$ denote second-period consumption under repayment and default respectively, and let us drop the arguments of $\hat{\gamma}\left(K_{1}, B_{1}\right)$ to save on notation. When policy is risky, firstorder condition (7) implies that $u^{\prime}\left(C_{0}\right)>\frac{\beta}{\beta^{*}} u^{\prime}\left(C_{1}^{R}\right)$ since $Q_{i}\left(W_{0}, B_{1}\right)<\beta^{*}$ and $B_{1} \frac{\partial Q_{i}\left(W_{0}, B_{1}\right)}{B_{1}}<0$. Subtracting $u^{\prime}\left(C_{0}\right) G(\hat{\gamma})$ from both sides of first-order condition (6) for investment we get

$$
u^{\prime}\left(C_{0}\right)[1-G(\hat{\gamma})]=\beta f^{\prime}\left(K_{1}\right) u^{\prime}\left(C_{1}^{R}\right)[1-G(\hat{\gamma})]+\beta f^{\prime}\left(K_{1}\right)\left[u^{\prime}\left(C_{1}^{D}\right)-u^{\prime}\left(C_{0}\right)\right] G(\hat{\gamma})
$$

At the risk-free level of capital, $f^{\prime}\left(K_{1}^{f}\right)=1 / \beta^{*}$ and we obtain

$$
[1-G(\hat{\gamma})]\left[u^{\prime}\left(C_{0}\right)-\frac{\beta}{\beta^{*}} u^{\prime}\left(C_{1}^{R}\right)\right]=G(\hat{\gamma})\left[\frac{\beta}{\beta^{*}} u^{\prime}\left(C_{1}^{D}\right)-u^{\prime}\left(C_{0}\right)\right] .
$$


From the above derivations and the fact that marginal utility upon default is smaller than marginal utility upon repayment, it must be that $u^{\prime}\left(C_{0}\right)>\frac{\beta}{\beta^{*}} u^{\prime}\left(C_{1}^{R}\right)>\frac{\beta}{\beta^{*}} u^{\prime}\left(C_{1}^{D}\right)$. This in turn implies that (16) cannot hold for $K_{1}=K_{1}^{f}$, as the RHS of is positive while the LHS is negative.

Second, I prove statement 1, i.e. that the risk-free policy is optimal when it is feasible. Let $K_{1}^{r}, B_{1}^{r}$ denote risky policy, and recall that $K_{1}^{f}, B_{1}^{f}$ denote risk-free policy. Under the risk-free policy, condition (7) implies that

$$
\frac{\beta}{\beta^{*}} u^{\prime}\left(W_{0}+\beta^{*} B_{1}^{f}-K_{1}^{f}\right)=u^{\prime}\left[f\left(K_{1}^{f}\right)-B_{1}^{f}\right] .
$$

When policy is risky, condition (7) implies that

$$
\frac{\beta}{\beta^{*}} u^{\prime}\left(W_{0}+Q_{i}\left(W_{0}, B_{1}^{r}\right) B_{1}^{r}-K_{1}^{r}\right)>u^{\prime}\left[f\left(K_{1}^{r}\right)-B_{1}^{r}\right] .
$$

By construction, risk-free consumption at $t=1$ must be larger than risky consumption at $t=1$ under repayment, which implies

$$
u^{\prime}\left[f\left(K_{1}^{f}\right)-B_{1}^{f}\right]<u^{\prime}\left[f\left(K_{1}^{r}\right)-B_{1}^{r}\right]
$$

Combining (17), (18) and (19) proves that $u\left(W_{0}+\beta^{*} B_{1}^{f}-K_{1}^{f}\right)>u\left(W_{0}+Q_{i}\left(W_{0}, B_{1}^{r}\right) B_{1}^{r}-K_{1}^{r}\right)$. By construction we can also prove that second-period utility under the risk-free policy must be larger than its equivalent under the risky policy, for any realization of $\gamma$.

\section{References}

Aguiar, Mark and Gita Gopinath, "Defaultable debt, interest rates and the current account," Journal of International Economics, June 2006, 69 (1), 64-83.

- and Manuel Amador, "Self-Fulfilling Debt Dilution: Maturity and Multiplicity in Debt Models," NBER Working Papers 24683, National Bureau of Economic Research, Inc June 2018.

_, _, and Gita Gopinath, "Investment Cycles and Sovereign Debt Overhang," Review of Economic Studies, 2009, 76 (1), 1-31. 
_, _, Emmanuel Farhi, and Gita Gopinath, "Coordination and Crisis in Monetary Unions," Quarterly Journal of Economics, 2015, 130, 1727-1779.

_, Satyajit Chatterjee, Harold Cole, and Zachary Stangebye, "Quantitative Models of Sovereign Debt Crises," NBER Working Papers 22125, National Bureau of Economic Research, Inc March 2016.

Arellano, Cristina, "Default Risk and Income Fluctuations in Emerging Economies," American Economic Review, 2008, 98 (3), 690-712.

_ and Yan Bai, "Fiscal Austerity during Debt Crises," Staff Report 525, Federal Reserve Bank of Minneapolis January 2016.

_ , _, and Luigi Bocola, "Sovereign Default Risk and Firm Heterogeneity," NBER Working Papers 23314, National Bureau of Economic Research, Inc April 2017.

Auclert, Adrien and Matthew Rognlie, "Unique equilibrium in the EatonGersovitz model of sovereign debt," Journal of Monetary Economics, 2016, 84 (C), 134-146.

Ayres, João, Gaston Navarro, Juan Pablo Nicolini, and Pedro Teles, "Sovereign default: The role of expectations," Journal of Economic Theory, 2018, 175 (C), 803-812.

Bai, Yan and Jing Zhang, "Financial integration and international risk sharing," Journal of International Economics, 2012, 86 (1), 17-32.

Balke, Neele, "The Employment Cost of Sovereign Default," Working Paper, UCL May 2017.

Balke, Neele L. and Morten O. Ravn, "Time-Consistent Fiscal Policy in a Debt Crisis," Discussion Papers 1638, Centre for Macroeconomics (CFM) November 2016.

Bassetto, Marco, "Equilibrium and government commitment," Journal of Economic Theory, September 2005, 124 (1), 79-105.

_ and Carlo Galli, "Is Inflation Default? The Role of Information in Debt Crises," Working Paper Series WP-2017-6, Federal Reserve Bank of Chicago March 2017. 
Bocola, Luigi, "The Pass-Through of Sovereign Risk," Journal of Political Economy, 2016, 124 (4), 879-926.

- and Alessandro Dovis, "Self-Fulfilling Debt Crises: A Quantitative Analysis," NBER Working Papers 22694, National Bureau of Economic Research, Inc September 2016.

Bottero, Margherita, Simone Lenzu, and Filippo Mezzanotti, "Sovereign Debt Exposure and the Bank Lending Channel: Impact on Credit Supply and the Real Economy," Working Paper, Harvard University OpenScholar December 2014.

Broner, Fernando, Aitor Erce, Alberto Martin, and Jaume Ventura, "Sovereign debt markets in turbulent times: Creditor discrimination and crowding-out effects," Journal of Monetary Economics, 2014, 61 (C), 114-142.

Calvo, Guillermo A, "Servicing the Public Debt: The Role of Expectations," American Economic Review, September 1988, 78 (4), 647-61.

Cole, Harold L. and Timothy J. Kehoe, "Self-Fulfilling Debt Crises," Review of Economic Studies, 2000, 67 (1), 91-116.

Conesa, Juan Carlos and Timothy J. Kehoe, "Gambling for redemption and self-fulfilling debt crises," Economic Theory, December 2017, 64 (4), 707-740.

Corsetti, Giancarlo and Luca Dedola, "The Mystery of the Printing Press: Monetary Policy and Self-Fulfilling Debt Crises," Journal of the European Economic Association, 2016, 14 (6), $1329-1371$.

Detragiache, Enrica, "Rational Liquidity Crises in the Sovereign Debt Market: In Search of a Theory," IMF Staff Papers, September 1996, 43 (3), 545-570.

Eaton, Jonathan and Mark Gersovitz, "Debt with Potential Repudiation: Theoretical and Empirical Analysis," Review of Economic Studies, April 1981, 48 (2), 289-309.

Gordon, Grey and Pablo Guerron-Quintana, "Dynamics of Investment, Debt, and Default," Review of Economic Dynamics, April 2018, 28, 71-95. 
Krugman, Paul, "Financing vs. forgiving a debt overhang," Journal of Development Economics, November 1988, 29 (3), 253-268.

Lamont, Owen, "Corporate-Debt Overhang and Macroeconomic Expectations," American Economic Review, December 1995, 85 (5), 1106-1117.

Lorenzoni, Guido and Ivan Werning, "Slow Moving Debt Crises," NBER Working Papers 19228, National Bureau of Economic Research, Inc July 2013.

Müller, Andreas, Kjetil Storesletten, and Fabrizio Zilibotti, "Sovereign Debt and Structural Reforms," CEPR Discussion Papers 10588, C.E.P.R. Discussion Papers May 2015.

Passadore, Juan and Juan Pablo Xandri, "Robust Predictions in Dynamic Policy Games," https://scholar.princeton.edu/sites/default/files/jxandri/files/px. nov_.18.final_.pdf 2018. Mimeo, Princeton University and Einaudi Institute for Economics and Finance.

Sachs, Jeffrey D, "Conditionality, debt relief, and the developing country debt crisis," in "Developing Country Debt and Economic Performance, Volume 1: The International Financial System," University of Chicago Press, 1989, pp. 255-296.

Stangebye, Zachary R., "Belief Shocks and Long-Maturity Sovereign Debt," Jan 2017. Mimeo. 